KAROLINA WALANCIK-RYBA

ORCID 0000-0002-9988-0145

Akademia WSB

w Dąbrowie Górniczej

\title{
RODZINA NATURALNA A RODZINA ZASTĘPCZA. POJĘCIA, PODOBIEŃSTWA I RÓŻNICE
}

\begin{abstract}
AвSTRACt. Walancik-Ryba Karolina, Rodzina naturalna a rodzina zastępcza. Pojęcia, podobieństwa i różnice [Natural Family and Foster Family. Concepts, Similarities and Differences]. Studia Edukacyjne nr 56, 2020, Poznań 2020, pp. 297-307. Adam Mickiewicz University Press. ISSN 1233-6688. DOI: 10.14746/ se.2020.56.16

The article "Natural Family and Foster Family. Concepts, Similarities and Differences" covers the problem of defining the terms: the family and the foster family. The author compares these concepts, focusing on the similarities and differences between the two. Based on the issues related to these concepts, she attempts to define the concept of the foster family.
\end{abstract}

Key words: family, foster family, child, parents, foster care

\section{Wstęp}

Rodzina jest określana jako podstawowa komórka społeczna, fundamentalny i konstytutywny element każdego społeczeństwa, jego główny budulec ${ }^{1}$. Stanowi najstarszą grupę społeczną, występującą we wszystkich etapach rozwoju społeczeństwa i we wszystkich formacjach².

Wskazać należy, że nadal aktualne pozostaje ujęcie prawne rodziny S. Grzybowskiego - jako najdrobniejszej lub drobnej grupy społecznej związanej wewnętrznie przesłankami wywodzącymi się z łączącego jej członków poczucia bliskości oraz wspólności osobistej i gospodarczej, w zasadzie,

${ }^{1}$ T. Szlendak, Socjologia rodziny. Ewolucja, historia, zróżnicowanie, Warszawa 2011, s. 95.

2 Art. 10 Międzynarodowego Paktu Praw Gospodarczych, Społecznych i Kulturalnych otwarty do podpisu w Nowym Yorku 19 grudnia 1966 r.; M. Andrzejewski, Prawna ochrona rodziny, Warszawa 1999, s. 14. 
i w przeważającej mierze, ale niekoniecznie, uzasadnionego pokrewieństwem - więzami krwi. Ład tej grupy zależał zawsze od panujących warunków społecznych i gospodarczych, właściwych dla określonej grupy rodzinnej

\section{Rodzina naturalna i rodzina zastępcza - charakterystyka pojęć}

Zgodnie z Konstytucją Rzeczypospolitej Polskiej, małżeństwo, jako związek kobiety i mężczyzny, rodzina, macierzyństwo i rodzicielstwo znajdują się pod ochroną, i opieką Rzeczypospolitej Polskiej. Każdy ma prawo do ochrony prawnej życia rodzinnego ${ }^{5}$, państwo w swojej polityce społecznej i gospodarczej uwzględnia dobro rodziny, a rodziny znajdujące się w trudnej sytuacji materialnej i społecznej (zwłaszcza wielodzietne i niepełne) mają prawo do szczególnej pomocy ze strony władz publicznych ${ }^{6}$.

W polskim ustawodawstwie brakuje jednak definicji pojęcia rodzina. Istnieją jedynie definicje stworzone "na potrzeby" interpretacji tego pojęcia w świetle konkretnych ustaw. Na przykład, definicję rodziny na potrzeby własnej regulacji zawiera Ustawa z 12 marca 2004 r. o pomocy społecznej, zgodnie z którą rodzinę tworzą osoby spokrewnione lub niespokrewnione pozostające w faktycznym związku, wspólnie ze sobą zamieszkujące i gospodarujące ${ }^{7}$, czy też Ustawa z 23 listopada 2003 r. o świadczeniach rodzinnych ${ }^{8}$, zgodnie z którą, ilekroć w ustawie mowa o rodzinie, oznacza to odpowiednio następujących członków rodziny: małżonków, rodziców dzieci, opiekuna faktycznego dziecka oraz pozostające na utrzymaniu dzieci $\mathrm{w}$ wieku do ukończenia dwudziestego piątego roku życia, a także dziecko, które ukończyło dwudziesty piąty rok życia legitymujące się orzeczeniem o znacznym stopniu niepełnosprawności, jeżeli w związku z tą niepełnosprawnością przysługuje świadczenie pielęgnacyjne lub specjalny zasiłek opiekuńczy albo zasiłek dla opiekuna, o którym mowa w Ustawie z 4 kwietnia 2014 r. o ustaleniu i wypłacie zasiłków dla opiekunów ${ }^{9}$. Do członków rodziny nie zalicza

\footnotetext{
${ }^{3}$ S. Grzybowski, Prawo rodzinne: zarys wykładu, Warszawa 1980, s. 11.

${ }^{4}$ Art. 18 Konstytucji Rzeczypospolitej Polskiej z 2 kwietnia 1997 r. (DzU 1997 nr 78, poz. 483), zwana dalej Konstytucją RP.

${ }^{5}$ Art. 47 Konstytucji RP.

${ }^{6}$ Art. 71 Konstytucji RP.

${ }^{7}$ Art. 6 pkt 14 Ustawy z 12 marca 2004 r. o pomocy społecznej (DzU 2004 nr 64, poz. 593 z późn. zm.).

${ }^{8}$ Art. 3 pkt 16 Ustawy z 28 listopada 2003 r. o świadczeniach rodzinnych (DzU 2003 nr 228, poz. 2255 z późn. zm.). $567)$.

${ }^{9}$ Ustawa z 4 kwietnia 2014 r. o ustaleniu i wypłacie zasiłków dla opiekunów (DzU poz.
} 
się dziecka pozostającego pod opieką opiekuna prawnego, dziecka pozostającego w związku małżeńskim, a także pełnoletniego dziecka posiadającego własne dziecko.

Brak zdefiniowania pojęcia rodziny $\mathrm{w}$ polskim ustawodawstwie uzasadnia się tym, że rodzina jest uznawana za zjawisko przede wszystkim socjologiczne, a w kręgu zainteresowania prawa pozostaje ze względu na swoją range $e^{10}$.

Rodzina stanowi podstawowy przedmiot zainteresowania prawa rodzinnego, co wynika już z samej nazwy. Obecnie ustawodawca używając pojęcia rodzina, ma najczęściej na uwadze rodzinę małą, składającą się z rodziców i dzieci. Rodziny w takim ujęciu dotyczy większość przepisów Kodeksu rodzinnego i opiekuńczego zwanego dalej k.r.o. ${ }^{11}$ Do pojęcia rodziny w szerszym zakresie nawiązują tylko nieliczne przepisy tego kodeksu i dotyczą przede wszystkim przepisów regulujących kwestie obowiązku alimentacyjnego ${ }^{12}$ między krewnymi oraz kwestie związane $\mathrm{z}$ powołaniem opiekuna prawnego dziecka ${ }^{13}$.

W rozumieniu przepisów k.r.o. pojęcie rodziny oparte jest na więzach małżeństwa, pokrewieństwa, powinowactwa i przysposobienia ${ }^{14}$. Rodzinę tworzą: małżonkowie, w tym również bezdzietni, wspólne małoletnie dzieci małżonków oraz dzieci pełnoletnie, które się nie usamodzielniły oraz dzieci przysposobionych małżonków.

Do rodziny nie należą natomiast $\mathrm{w}$ świetle tych przepisów: dzieci jednego małżonka, nawet jeżeli zostały wychowane przez nich we wspólnie założonej rodzinie oraz dzieci wzięte na wychowanie (nieprzysposobione), a zatem również dzieci umieszczone $\mathrm{w}$ pieczy zastępczej.

$\mathrm{Z}$ chwilą usamodzielnienia się dzieci przestają tworzyć rodzinę małą wraz ze swoimi rodzicami, a przyjmuje się, że zaczynają tworzyć rodzinę, jako sformalizowaną komórkę społeczną, poprzez zawarcie małżeństwa ${ }^{15}$. Zatem, założenie rodziny przez zawarcie małżeństwa zależy od inicjatywy i woli osób zainteresowanych, ale odbywa się pod kontrolą państwa ${ }^{16}$.

$\mathrm{W}$ ujęciu prawnym, odmiennie niż w ujęciu socjologicznym, przez rodzinę należy również rozumieć bezdzietne małżeństwo. Co ważne, w ujęciu

\footnotetext{
${ }^{10}$ A. Zieliński, Prawo rodzinne i opiekuńcze w zarysie, Warszawa 2011, s. 37.

${ }^{11}$ Ustawa z 25 lutego 1964 r. Kodeks rodzinny i opiekuńczy (DzU 1964 nr 9, poz. 59 z późn. zm.), zwana dalej k.r.o., wyjątki art. 14 §1 k.r.o., art. 128 k.r.o., art. 129 k.r.o., art. 144 k.r.o., art. 149 §2 k.r.o.

12 Art. 128 k.r.o.

13 Art. 149 k.r.o.

${ }^{14}$ J. Ignatowicz, M. Nazar, Prawo rodzinne, Warszawa 2005, s. 22.

15 Art. 1 i art. 27 k.r.o.

${ }_{16}$ T. Smyczyński, w: T. Smyczyński i in., System prawa prywatnego. Prawo rodzinne i opiekuńcze, Warszawa 2009, s. 2.
} 
prawnym fundamentem rodziny jest para składająca się z kobiety i mężczyzny, a nie para jednorodna płciowo. Na gruncie prawa rodzinnego faktyczne pożycie kobiety i mężczyzny niebędących małżeństwem jest nieunormowane. Jedynie ustawodawstwo socjalne, na przykład w zakresie pomocy społecznej adresuje pewne normy również do konkubentów. Pomimo że polskie prawo rodzinne preferuje rodzinę opartą na małżeństwie, nie oznacza to nierównej sytuacji dzieci zrodzonych ze związku pozamałżeńskiego; preferencja ta kreuje jedynie stabilną sytuację małżonków $w^{17}$.

Zatem, przy tak przyjętym w prawie rozumieniu pojęcia rodzina, wskazać należy, że konkubinat ${ }^{18}$, czyli nieuregulowana przez ustawę trwała wspólnota życiowa mężczyzny i kobiety ${ }^{19}$, nie tworzy rodziny, ale może wspólnie wykonywać władzę rodzicielską nad wspólnymi małoletnimi dziećmi, jednak każdy czyni to w odrębnym stosunku władzy rodzicielskiej ${ }^{20}$. Zatem, jest to stosunek społeczny a nie prawny, albowiem u źródeł jego powstania nie tkwi zdarzenie prawne, dzięki któremu uzyskiwałby on cechy stosunku prawnego $^{21}$. W tym miejscu pojawia się pytanie: czy konkubinat może stanowić źródło rodziny w sytuacji, kiedy osoby żyjące w konkubinacie zawrą związek małżeński?

Ponadto, czy konkubinat może prowadzić do powstania rodziny w rozumieniu przepisów prawa rodzinnego w sytuacji urodzenia się dziecka z tego związku? Według J. Piątowskiego, rodzina opiera się wówczas na macierzyństwie konkubiny i ustalonym $\mathrm{w}$ trybie uznania albo w wyroku sądowym ojcostwie konkubenta ${ }^{22}$.

Rodzina jest zorganizowaną jednostką społeczną, jednak nie posiada osobowości prawnej, nie funkcjonuje jako podmiot praw i obowiązków, a tym samym nie jest właścicielem przedmiotów majątkowych, nie może wnieść powództwa. W świetle obowiązujących przepisów, w rodzinie dostrzega się wielość stosunków prawnych między jej członkami ${ }^{23}$.

Termin rodzina rzadko występuje w k.r.o. Ponadto, można zauważyć brak konsekwencji ustawodawcy w używaniu powyższego terminu. W art. 27 k.r.o., zgodnie z którym oboje małżonkowie obowiązani są, każdy według swych sił oraz swych możliwości zarobkowych i majątkowych, przy-

17 Tamże, s. 5.

18 Concubinatus - instytucja znana prawu rzymskiemu; doktryna polska jako cechy charakterystyczne dla konkubinatu wyróżnia: związek mężczyzny i kobiety, trwałość tego związku, pożycie jak w małżeństwie, brak zdarzenia prawnego regulującego ten związek.

19 A. Zieliński, Prawo rodzinne i opiekuńcze w zarysie, s. 41.

20 Art. $107 \S 1$ k.r.o.

${ }^{21}$ J. Piątowski w: J. Piątowski i in., System prawa rodzinnego i opiekuńczego, Wrocław 1985, s. 43 .

22 Tamże, s. 44.

23 Tamże, s. 40. 
czyniać się do zaspokajania potrzeb rodziny, którą przez swój związek założyli, za rodzinę uznać należy małżonków i ich wspólne dzieci, w tym dzieci przysposobione. Natomiast, w przypadku art. 134 k.r.o., zgodnie z którym, w stosunku do rodzeństwa, zobowiązany może uchylić się od świadczeń alimentacyjnych, jeżeli są one połączone $z$ nadmiernym uszczerbkiem dla niego lub dla jego najbliższej rodziny, zgodnie z przyjętą doktryną i piśmiennictwem za rodzinę uznać należy małżonka, dzieci, a ponadto rodzica zobowiązanego do alimentacji.

Zgodnie z Ustawą z 9 czerwca 2011 r. o wspieraniu rodziny i systemie pieczy zastępczej ${ }^{24}$, rodzina jest podstawową komórką społeczeństwa oraz naturalnym środowiskiem rozwoju i dobra wszystkich jej członków, a w szczególności dzieci.

Odnośnie rodziny zastępczej ${ }^{25}$ należy wskazać, że zarówno k.r.o., jak i Ustawa o wspieraniu rodziny nie definiują tego pojęcia. Kodeks zawiera jedynie przepisy regulujące kwestie tworzenia rodzin zastępczych ${ }^{26} . \mathrm{W}$ zakresie organizacji, funkcjonowania i finansowania tych rodzin k.r.o. odsyła do przepisów o wspieraniu rodziny i systemie pieczy zastępczej ${ }^{27}$.

Dokonując literalnej wykładni tego pojęcia, należałoby uznać, że rodzina zastępcza to rodzina, która „zastępuje" rodzinę naturalną. Pojęcie rodziny nie jest zatem pojęciem, które zawiera w sobie pojęcie rodziny zastępczej. Nie są to pojęcia tożsame, co wynika już z samego założenia istnienia instytucji rodziny zastępczej ${ }^{28}$.

Rozwiązaniem zawartym w Ustawie o wspieraniu rodziny jest określenie pojęcia rodziny zastępczej spokrewnionej z dzieckiem poprzez sprecyzowanie, kto taką rodzinę tworzy. Rodziny zastępcze spokrewnione z dzieckiem tworzone są przez wstępnych (innych niż rodzice, a więc przede wszystkim przez dziadków) oraz przez rodzeństwo (także przyrodnie). Jeżeli rodzi-

${ }^{24}$ Ustawa z 9 czerwca 2011 r. o wspieraniu rodziny i systemie pieczy zastępczej (DzU 2011 nr 149, poz. 887 z późn. zm.) zwana dalej Ustawą o wspieraniu rodziny; zob. European Social Network, Foster care models in Europe, https://www.esn-eu.org/news/59/index.html, [dostęp: 31.01.2020].

${ }_{25}$ Zob. FRA European Union Agency for Fundamental Rights, Standards on foster care, https://fra.europa.eu/en/publication/2015/mapping-child-protection-systems-eu/foster-care, [dostęp: 31.01.2020]; M. Laklija, Foster care models in Europe-results of the conducted survey, Zagreb October 2011, https://www.udomiteljizadjecu.hr/wp-content/uploads/documents/publikacije/Foster\%20care\%20models\%20in \%20Europe\%20-\%20results\%20of\%20a\%20conducted \%20 survey\%20-\%20Maja\%20Laklija.pdf, s. 6, [dostęp: 31.01.2020]; A. Polkowska, T. Polkowski, Perspective of Family Foster Care in Poland, Czech Republic, Slovakia and Hungary, http://fdir.pl/images/wyszegrad/Pl_final.pdf, s. 5, [dostęp: 31.01.2020].

${ }^{26}$ Oddział 2a k.r.o.

27 Art. 1122 k.r.o.

${ }_{28}$ Zob. J. Boddy, Understanding permanence for looked after children: A review of research for the Care Inquiry, The Care Inquiry, London 2013 https:/ / www.thefosteringnetwork.org.uk/sites/ www.fostering.net/files/resources/ Models in europe 
nę zastępczą utworzy dla dziecka jakikolwiek inny krewny w linii bocznej niż rodzeństwo, czy też osoba spowinowacona $z$ dzieckiem, nie mówiąc już o osobach spoza szeroko rozumianej rodziny, to - $\mathrm{w}$ świetle obecnie obowiązujących przepisów - powstanie w ten sposób rodzina zastępcza niespokrewniona z dzieckiem ${ }^{29}$.

Ustawodawca $\mathrm{w}$ uzasadnieniu projektu Ustawy o wspieraniu rodziny wskazał, że określenie rodziny zastępczej spokrewnionej znajduje potwierdzenie w zasadach związanych zarówno z prymatem rodziny, w kwestii odpowiedzialności za dziecko, jak i zasadą pomocniczości państwa w udzielaniu pomocy oraz opieki dzieciom pozbawionym opieki rodzicielskiej. Ponadto podał, że wyżej wymienione rozwiązanie ma swoje uzasadnienie w przepisach k.r.o., ponieważ uwzględnia osoby, na których, z mocy prawa, ciąży obowiązek alimentacyjny. Pomimo że stwierdzenie istnienia i określenie wysokości obowiązku alimentacyjnego w stosunku do zobowiązanych w dalszej kolejności (np. dziadkowie, rodzeństwo) jest zależne od wielu czynników związanych z dzieckiem, jak i osobami zobowiązanymi, to nie zmienia to faktu, że - z samej istoty więzów rodzinnych i prawnych - osoby te znajdują się w kręgu osób odpowiedzialnych za utrzymanie dziecka pozbawionego opieki rodziców ${ }^{30}$.

W postanowieniu z 9 września 1998 r. Sąd Najwyższy ${ }^{31}$ podkreślił, że rodzina zastępcza powinna w maksymalnym stopniu być zbliżona do rodziny naturalnej, co oznacza, że powinna mieć oboje rodziców, w odpowiednim wieku, a ponadto posiadać odpowiednie kwalifikacje moralne i predyspozycje wychowawcze.

\section{Rodzina naturalna a rodzina zastępcza - komparatystyka instytucji}

Analizując przepisy dotyczące rodziny zastępczej, ujawniają się różnice, które wynikają przede wszystkim z celu umieszczenia dziecka w tej rodzinie. Celem tym jest, w sytuacji zagrożenia dobra dziecka, zastąpienie rodziny do czasu zaistnienia warunków umożliwiających jego powrót do rodziny albo w sytuacji, gdy powrót dziecka do rodziny okazałby się niemożliwy, do umieszczenia go $\mathrm{w}$ rodzinie przysposabiającej ${ }^{32}$.

${ }^{29}$ B. Mazurkiewicz, Nowelizacja ustawy o wspieraniu rodziny $i$ systemie pieczy zastępczej, komentarz praktyczny ABC, nr 150010, LEX.

${ }^{30}$ Uzasadnienie do projektu ustawy o rodzinnej opiece zastępczej, Druk Sejmowy nr 628, Sejm RP VI kadencji.

${ }^{31}$ Postanowienie SN z 9 września 1998 r. I CKN 197/98, nr 1215918, LEX.

${ }^{32}$ Art. 1124 k.r.o. 
Umieszczenie dziecka $\mathrm{w}$ rodzinie zastępczej następuje na okres nie dłuższy niż do osiągnięcia pełnoletniości ${ }^{33}$, ewentualnie do dwudziestego piątego roku życia przy spełnieniu dodatkowych wskazanych w ustawie wymogów ${ }^{34}$. Zatem, rodzinę zastępczą, przynajmniej z założenia, cechuje tymczasowość. W stosunku do rodzin zastępczych tymczasowość nie powinna być postrzegana negatywnie. Na tymczasowość należy bowiem patrzeć przez pryzmat podstawowego celu umieszczenia dziecka poza rodziną, jakim jest udzielanie wsparcia dziecku i jego rodzinie. Tymczasowość rodzin zastępczych ma służyć odbudowaniu stabilności rodzin naturalnych (reintegracja) ${ }^{35}$. Do każdego z przypadków należy jednak podchodzić indywidualnie. W sytuacji bowiem, kiedy, pomimo wysiłków, nie uda się przywrócić dziecka jego rodzicom lub też w sytuacji, gdy od początku wiadomo, że osiągnięcie tego celu zdane jest na niepowodzenie, należy stworzyć dziecku zastępcze środowisko rodzinne o charakterze trwałym, czyli takie, w którym będzie mogło przebywać do osiągnięcia dorosłości. Wskazać również należy, że ideę tymczasowości wspierają przepisy dotyczące kontaktów z dzieckiem zawarte zarówno w k.r.o., jak i w Ustawie o wspieraniu rodziny. Stosowane są one również do kontaktów z dziećmi umieszczonymi w rodzinach zastępczych. Nieodzowne bowiem dla zrealizowania celu umieszczenia dziecka w rodzinie zastępczej, jakim jest reintegracja rodziny, jest utrzymywanie tych kontaktów przez rodziców i inne osoby bliskie dziecku ${ }^{36}$.

Rodzina naturalna ma natomiast cechę trwałości ${ }^{37}$, jej byt nie jest uzależniony od jej pełnego składu. Na przykład, w przypadku śmierci jednego z małżonków bądź rozwodu, rodzina istnieje nadal i tworzy ją jeden z małżonków oraz dzieci, które pozostają z tym małżonkiem we wspólnocie. Jak wcześniej wskazano, rodzinę w świetle obowiązujących przepisów i ich interpretacji tworzą już sami małżonkowie poprzez zawarcie małżeństwa. Za rodzinę, w najczęstszym ujęciu na gruncie prawnym, uważa się małżeństwo wraz ze wspólnymi dziećmi. Natomiast, zgodnie z k.r.o. rodzinę za-

${ }^{33}$ Art. 37 ust. 1 Ustawy o wspieraniu rodziny.

${ }^{34}$ Art. 37 ust. 2 Ustawy o wspieraniu rodziny.

${ }^{35}$ M. Safjan, Instytucja rodzin zastępczych: Problemy prawno-organizacyjne, Warszawa 1982, s. 24-25 i 204; J. Winiarz, Prawo rodzinne, Warszawa 1996, s. 264; M. Andrzejewski, Instytucja rodzin zastępczych w świetle nowych regulacji prawnych, Problemy Opiekuńczo-Wychowawcze, 1999, 8; tenże, Prawo dziecka do pieczy zastępczej, w: T. Smyczyński (red.), Konwencja o Prawach Dziecka. Analiza i wykładnia, Poznań 1999, s. 167 i n. (odstępując od poglądów wyrażonych wcześniej w recenzji pracy M. Safjana, Instytucja rodzin zastępczych, Ruch Prawniczy, Ekonomiczny i Socjologiczny, 1983, 3, ROK XLV, s. 261-263); tenże, Rodziny zastępcze - charakterystyka prawna, [w:] Rodziny zastępcze - problematyka prawna, red. M. Andrzejewski, Toruń 2006, s. 19-28; tenże, Ochrona praw dziecka w rodzinie dysfunkcyjnej, Kraków 2003, s. 212-229.

${ }^{36}$ H. Szurgacz, Naganne zachowanie świadczeniobiorcy jako przestanka ograniczenia ochrony w prawie pomocy społecznej, Acta Universitatis Wratislaviensis - Prawo, 1994, 238, s. 154.

37 T. Smyczyński, Prawo rodzinne i opiekuńcze, Warszawa 2005, s. 1. 
stępczą mogą tworzyć: małżonkowie albo osoba niepozostająca w związku małżeńskim, którzy są wstępnymi albo rodzeństwem dziecka, jak również małżonkowie albo osoba niepozostająca w związku małżeńskim, którzy nie są wstępnymi albo rodzeństwem dziecka, jeżeli osoby te zostały wpisane do rejestru osób zakwalifikowanych do pełnienia funkcji rodziny zastępczej zawodowej, rodziny zastępczej niezawodowej, prowadzenia rodzinnego domu dziecka albo pełnią już funkcję rodziny zastępczej zawodowej lub rodziny zastępczej niezawodowej oraz prowadzących rodzinny dom dziecka. Jeżeli jest to uzasadnione dobrem dziecka, sąd może tymczasowo, nie dłużej jednak niż na 6 miesięcy, powierzyć pełnienie funkcji rodziny zastępczej małżonkom albo osobie niepozostającej w związku małżeńskim, którzy nie są wstępnymi albo rodzeństwem dziecka, niespełniającym warunku niezbędnych szkoleń, określonego w przepisach o wspieraniu rodziny i systemie pieczy zastępczej, dotyczących rodzin zastępczych ${ }^{38}$. W tym przepisie ustawodawca określa, komu sąd może powierzyć sprawowanie pieczy zastępczej i jakie warunki są niezbędne, aby tę pieczę tym osobom powierzyć. Przepis ten dotyczy wyłącznie rodzin zastępczych i jest on formalną podstawą podziału rodzin zastępczych na spokrewnione i niespokrewnione z wychowankiem ${ }^{39}$.

Jak wcześniej wskazano, Ustawa o wspieraniu rodziny nie zawiera definicji rodziny zastępczej, wymienia ją jedynie jako formę rodzinnej pieczy zastępczej $^{40}$. Doprecyzowuje i charakteryzuje ona pojęcie rodziny zastępczej poprzez wskazanie, kto rodzinę zastępczą tworzy. Zgodnie z Ustawą o wspieraniu rodziny, rodzinę zastępczą tworzą małżonkowie lub osoba niepozostająca w związku małżeńskim ${ }^{41}$.

Zgodnie z wyżej wymienionymi przepisami, rodziną zastępczą mogą być osoby, które są małżeństwem ${ }^{42} \mathrm{~W}$ rozumieniu prawa cywilnego, a zatem osoby, które zawarły tak zwany ślub cywilny lub tak zwane małżeństwo konkordatowe, jak również osoby niepozostające w związku małżeńskim. Powyższe oznacza, że rodzinę zastępczą mogą tworzyć zarówno osoby samotne, jak i żyjące w konkubinacie. A zatem, dla powstania rodziny zastępczej, inaczej niż w przypadku rodziny w ujęciu prawnym, zawarcie małżeństwa nie jest konieczne. Rodzina zastępcza powstaje bowiem z chwilą umieszczenia w niej dziecka i objęcia nad nim faktycznej pieczy ${ }^{43}$, i funkcjonuje na podstawie orzeczenia sądu bądź umowy cywilnoprawnej. Rodziny zastępcze w świetle obowiązujących przepisów dzielą się na spokrewnione, niezawodowe i za-

38 Art. 1125 k.r.o.

${ }^{39}$ M. Andrzejewski i in., Kodeks Rodzinny i Opiekuńczy, red. H. Dolecki, T. Sokołowski, Warszawa 2013, s. 768.

${ }^{40}$ Art. 39 ust. 1 Ustawy o wspieraniu rodziny.

${ }^{41}$ Art. 41 ust. 1 Ustawy o wspieraniu rodziny.

${ }^{42}$ Art. $1 \S 1$ k.r.o.

${ }^{43}$ Art. 55 i art. 58 Ustawy o wspieraniu rodziny. 
wodowe. Rodziny zastępcze spokrewnione z dzieckiem tworzone są przez wstępnych (innych niż rodzice, a więc przede wszystkim dziadków) oraz rodzeństwo, w tym przyrodnie. Natomiast, jeżeli rodzinę zastępczą utworzy jakikolwiek inny krewny w linii bocznej, czy też powinowaty (np. małżonek dziadka), jak również rodzeństwo tak zwane przybrane (pochodzące z innego związku macochy czy ojczyma), zgodnie z aktualnie obowiązującymi przepisami - powstanie rodzina zastępcza niezawodowa. $\mathrm{W}$ obecnie obowiązujących przepisach brak pojęcia rodziny zastępczej niespokrewnionej, a krąg osób tworzących rodzinę zastępczą spokrewnioną jest ograniczony i nie pokrywa się z pojęciem pokrewieństwa. Zatem, zgodnie z literalnym brzmieniem art. 41 ust. 1. Ustawy o wspieraniu rodziny, należałoby uznać, że brat małoletniego tworzy rodzinę zastępczą spokrewnioną, natomiast brat małoletniego z żoną - rodzinę zastępczą niezawodową, co nie wydaje się być zamierzeniem ustawodawcy.

\section{Zakończenie}

Konkludując, należy stwierdzić, że problematyka dotycząca pojęć: rodzina i rodzina zastępcza jest złożona i skomplikowana. Potwierdzenie powyższego stanowi fakt, że nadal nie wypracowano definicji tych pojęć. Podejmując próbę zdefiniowania pojęcia rodzina zastępcza, przy uwzględnieniu powyższych rozważań, należałoby uznać, że jest to uregulowana przepisami prawa, podlegająca okresowej weryfikacji instytucja, którą tworzą osoby spokrewnione bądź niespokrewnione $\mathrm{z}$ dzieckiem w celu zapewnienia mu warunków życia według wzorca rodziny naturalnej do czasu zaistnienia możliwości powrotu dziecka do rodziny, bądź umieszczenia go w rodzinie przysposabiającej.

\section{BIBLIOGRAFIA}

Andrzejewski M., Instytucja rodzin zastępczych w świetle nowych regulacji prawnych, Problemy Opiekuńczo-Wychowawcze, 1999, 8, Instytut Rozwoju Służb Publicznych.

Andrzejewski M., Prawna ochrona rodziny, Wydawnictwa Szkolne i Pedagogiczne, Warszawa 1999.

Andrzejewski M., Ochrona praw dziecka w rodzinie dysfunkcyjnej, Kantor Wydawniczy Zakamycze, Kraków 2003.

Andrzejewski M., Gąsiorek P., Ławrynowicz P., Synoradzka M., Rodziny zastępcze - problematyka prawna, red. M. Andrzejewski, TNOiK - Towarzystwo Naukowe Organizacji i Kierowania. „Dom Organizatora”, Torun 2006. 
Andrzejewski M., Dolecki H., Haberko J., Lutkiewicz-Rucińska A., Olejniczak A., Sokołowski T., Sylwestrzak A., Zielonacki A., Kodeks Rodzinny i Opiekuńczy, red. H. Dolecki, T. Sokołowski, Wolters Kluwer SA, Warszawa 2013.

Boddy J., Understanding permanence for looked after children: A review of research for the Care Inquiry, The Care Inquiry, London 2013.

https://www.thefosteringnetwork.org.uk/sites/www.fostering.net/files/resources/england/understanding-permanence-for-lac-janet-boddy.pdf, [dostęp: 31.01.2020].

European Social Network, Foster care models in Europe, https:/ / www.esn-eu.org/news/59/ index.html, [dostęp: 31.01.2020].

FRA European Union Agency for Fundamental Rights, Standards on foster care, https:/ / fra.europa.eu/en/publication/2015/mapping-child-protection-systems-eu/fostercare, [dostęp: 31.01.2020].

Grzybowski S., Prawo rodzinne: zarys wykładu, Państwowe Wydawnictwo Naukowe, Warszawa 1980.

Ignatowicz J., Nazar M., Prawo rodzinne, LexisNexis, Warszawa 2005.

Laklija M., Foster care models in Europe - results of the conducted survey, Zagreb October 2011, https://www.udomiteljizadjecu.hr/wp-content/uploads/documents/publikacije/ Foster \% 20care \%20models \%20in \% 20Europe \% 20-\%20results $\% 20$ of $\% 20$ a \% 20conducted\%20survey\%20-\%20Maja\%20Laklija.pdf, [dostęp: 31.01.2020].

Mazurkiewicz B., Nowelizacja ustawy o wspieraniu rodziny i systemie pieczy zastępczej, komentarz praktyczny ABC, nr 150010, LEX 2013.

Piątkowski J., Winiarz J., Ignatowicz J., Gwiazdomorski J., System prawa rodzinnego i opiekuńczego, red. J. Piątowski, Zakład Narodowy im. Ossolińskich, Wrocław 1985.

Polkowska A., Polkowski T., Perspective of Family Foster Care in Poland, Czech Republic, Slovakia and Hungary, http://fdir.pl/images/wyszegrad/Pl_final.pdf, [dostęp: 31.01.2020].

Safjan M., Instytucja rodzin zastępczych: Problemy prawno-organizacyjne, Wydawnictwo Prawnicze, Warszawa 1982.

Safjan M., Instytucja rodzin zastępczych, Ruch Prawniczy, Ekonomiczny i Socjologiczny, 1983, 3, ROK XLV, Wydział Prawa i Administracji UAM w Poznaniu.

Smyczyński T. (red.), Konwencja o Prawach Dziecka. Analiza i wykładnia, Ars boni et aequi, Poznań 1999.

Smyczyński T., Prawo rodzinne i opiekuńcze. Analiza i wykładnia, Wydawnictwo C.H. Beck, Warszawa 2001.

Smyczyński T., Prawo rodzinne i opiekuńcze, Wydawnictwo C.H. Beck, Warszawa 2005.

Smyczyński T., Gajda J., Nazar M., Panowicz-Lipska J., Sokołowski T., Stojanowska W., System prawa prywatnego. Prawo rodzinne i opiekuńcze, Wydawnictwo C.H. Beck, Warszawa 2009.

Szurgacz H., Naganne zachowanie świadczeniobiorcy jako przestanka ograniczenia ochrony w prawie pomocy społecznej, Acta Universitatis Wratislaviensis - Prawo, 1994, 238, Wydawnictwo Uniwersytetu Wrocławskiego.

Winiarz J., Prawo rodzinne, Wydawnictwo Naukowe PWN, Warszawa 1996.

Zieliński A., Prawo rodzinne i opiekuńcze w zarysie, Wolters Kluwer SA, Warszawa 2011.

\section{Akty prawne}

1. Konstytucja Rzeczypospolitej Polskiej z 2 kwietnia 1997 r. (DzU 1997 nr 78, poz. 483 z późn. zm.).

2. Ustawa z 12 marca 2004 r. o pomocy społecznej (DzU 2004 nr 64, poz. 593 z późn. zm.). 
3. Ustawa z 4 kwietnia 2014 r. o ustaleniu i wypłacie zasiłków dla opiekunów (DzU poz. 567).

4. Ustawa z 25 lutego 1964 r. Kodeks rodzinny i opiekuńczy (DzU 1964 nr 9, poz. 59 z późn. $\mathrm{zm}$.).

5. Ustawa z 28 listopada 2003 r. o świadczeniach rodzinnych (DzU 2003 nr 228, poz. 2255 z późn. zm.).

6. Ustawa z 9 czerwca 2011 r. o wspieraniu rodziny i systemie pieczy zastępczej (DzU 2011 nr 149, poz. 887 z późn. zm.).

7. Międzynarodowy Pakt Praw Gospodarczych, Społecznych i Kulturalnych otwarty do podpisu w Nowym Yorku 19 grudnia 1966 r. (DzU 1977 nr 38, poz. 169).

\section{Orzecznictwo}

1. Postanowienie SN z 9 września 1998 r. I CKN 197/98, nr 1215918, LEX. 